\title{
FENOMENA SAHAM TIDUR DAN KINERJANYA
}

\author{
Erpina Desy Christina Sihombing \\ Fakultas Ekonomika dan Bisnis Universitas Kristen Satya Wacana
}

\section{Supramono}

Fakultas Ekonomika dan Bisnis Universitas Kristen Satya Wacana supramono@staff.uksw.edu

\begin{abstract}
Sleeping stocks are the stocks that are not actively traded in a certain period. The aim of this is to analyze performance of the companies whose stocks are "sleeping" in Indonesia Stock Exchange. Employing purposive sampling technique, 66 stocks were selected. The analysis of the companies' performance was done by using market capitalization and the financial ratios that consist of return on asset ratio, return on equity and earnings per share, during 2010-2012. The result of this study showed companies with small capitalization and poor perfomance tend to have sleeping stocks
\end{abstract}

Keywords: sleeping stock, company performance, market capitalization, financial ratio.

\section{PENDAHULUAN}

Saham-saham yang tidak aktif diperdagangkan atau dikenal sebagai saham tidur merupakan salah satu fenomena perdagangan saham yang terjadi di Bursa Efek Indonesia (BEI). Berdasarkan data Bisnis Indonesia Intelligence Unit (BIIU), terdapat 118 saham tidur selama periode Januari 2010 hingga Juni 2011 dengan tingkat transaksi di bawah 40 persen dalam satu periode perdagangan, bahkan sebanyak 14 saham tercatat tidak melakukan transaksi perdagangan sama sekali atau tingkat transaksi nol persen (Ipot News, 18 Juli 2011).

Salim (2010) menjelaskan saham tidur merupakan saham yang tidak aktif diperdagangkan (tidak likuid) dalam jangka waktu yang lama. Berdasarkan Surat Edaran PT BEJ No. SE-03/BEJ II-1/I/1994 menyatakan bahwa suatu saham dikatakan aktif apabila frekuensi perdagangan saham selama tiga bulan sebanyak 75 kali atau lebih, dengan demikian apabila frekuensi perdagangan saham kurang dari 75 kali selama tiga bulan maka saham tersebut tidak aktif, sehingga lama kelamaan menjadi saham tidur dan tidak likuid.

Basir dan Hendy (2005) menegaskan ada dua kemungkinan penyebab dari saham tidur, pertama saham tersebut cukup prospektif dalam memberikan dividen yang teratur sehingga diminati investor jangka panjang, yang menyebabkan pemegang saham menjadi tidak tertarik untuk melepas sahamnya, kedua karena 
saham tersebut memang tidak menarik dan tidak berprospek. Selain itu ada kemungkinan terbatasnya jumlah saham yang dipasarkan menyebabkan tidak banyak transaksi yang terjadi dan saham dikuasai oleh investor institusi dan pemilik saham lama (pendiri perusahaan). Penyebab lainnya kurangnya transparansi terhadap ekspansi perusahaan sehingga pelaku pasar tidak dapat mempelajari prospek perusahaan ke depan yang secara tidak langsung berdampak pada pergerakan saham, padahal tidak semua saham yang tidur kinerja perusahaanya buruk (Investor Daily Indonesia, 20 Februari 2011).

Kinerja perusahaan yang memilki saham tidur tersebut hingga kini masih merupakan teka-teki karena sebelumnya tidak menjadi perhatian para peneliti. Selama ini penelitian mengenai kinerja perusahaan lebih didominasi pada kinerja perusahaan yang sahamnya likuid atau aktif diperdagangkan, diantaranya penelitian Afiff dan Samuel (2013), Setyawan dan Redha (2013) tentang kinerja perusahaan yang masuk LQ45, Fang et al. (2009), Wira (2012), Hansen dan Kim (2013) kaitan antara kinerja perusahan dan likuiditas saham. Pada umumnya penelitian tersebut menemukan bukti empiris bahwa kinerja perusahaan berpengaruh positif terhadap tingkat likuiditas sahamnya.

Bhunia et al. (2011) menyatakan bahwa analisis kinerja perusahaan merupakan penentuan efisiensi kinerja manajemen perusahaan yang tercermin dalam laporan keuangan. Sementara Gitman dan Chad (2012) mengungkapkan analisis perusahaan merupakan suatu penilaian terhadap kinerja perusahaan pada waktu yang lalu dan prospek pada masa datang. Untuk mengukur prospek perusahaan sering digunakan proksi Investment Opportunity Set (IOS), yang menunjukan prospek perusahaan yang tercermin dari banyaknya kesempatan yang tersedia untuk investasi (Kallapur dan Mark 2001; Puspitasari 2012). Namun, untuk kasus sahamnya tidur proksi IOS tidak dapat digunakan karena proksi IOS membutuhkan pertumbuhan nilai pasar perusahan sehingga penilaian kinerja perusahan yang memiliki saham tidur hanya bertumpu pada kinerja masa lalu dengan menggunakan rasio profitabilitas yaitu Return on Asset (ROA), Return on Equity (ROE) dan Earning per Share (EPS).

Berdasarkan uraian diatas maka penelitian ini dimaksudkan untuk mengekplorasi apa yang melatarbelakangi munculnya fenomena saham tidur ini di BEI dilihat dari sisi jumlah saham yang beredar dan kinerja perusahaannya baik yang bersifat time series maupun cross section sehingga dapat diketahui apakah terdapat kecenderungan perusahaan yang memiliki saham tidur merupakan perusahaan kecil dan kurang bagus kinerjanya sehingga tidak menarik teori investor.

\section{METODA PENELITIAN}

Data yang digunakan dalam penelitian ini adalah laporan keuangan tahunan, jumlah saham beredar dan harga penutupan saham selama periode 2010-2012 yang di unduh dalam situs resmi BEI (http://www.idx.co.id).Pemilihan sampel berdasarkan 
metoda purposive sampling dengan beberapa kriteria: (a) Saham tidur dengan kategori tidak aktif diperdagangkan selama tahun 2010, kriteria saham aktif berdasarkan Surat Edaran PT BEJ No. SE-03/BEJ II-1/I/1994, yaitu saham yang memiliki frekuensi perdagangan sebanyak 75 kali atau lebih selama tiga bulan, apabila frekuensi perdagangan kurang dari 75 kali maka saham dikatakan tidak aktif, (b) perusahaan yang masih terdaftar di BEI hingga tahun 2013, (c) perusahaan yang menerbitkan laporan keuangan tahunan per 31 Desember untuk periode tahun 20102012. Untuk proses pemilihan sampel berdasarkan kriteria di atas dapat dilihat pada Tabel 1. Dari total 66 sampel perusahaan yang terpilih, jumlah sampel terbesar berada pada sektor perdagangan jasa, investasi dan keuangan sebanyak 32 perusahaan (48 persen), sedangkan 52 persen tersebar pada sektor lainnya.

Tabel 1

Proses Pemilihan Sampel

\begin{tabular}{llc}
\multicolumn{3}{c}{ Proses Pemilihan Sampel } \\
\hline No & \multicolumn{1}{c}{ Proses } & Jumlah \\
\hline 1 & Saham tidur selama tahun 2010 & 71 \\
2 & $\begin{array}{l}\text { Penghapusan pencatatan (delisting) } \\
\text { saham pada tahun 2010-2013 }\end{array}$ & $(4)$ \\
3 & $\begin{array}{l}\text { Perusahaan yang menerbitkan laporan } \\
\text { keuangan tahunan per Maret }\end{array}$ & $(1)$ \\
4 & Sampel akhir & 66 \\
\hline
\end{tabular}

Tahapan analisis yang dilakukan dalam penelitian ini yaitu, melakukan analisis statistik deskriptif kinerja perusahaan pada periode tahun 2010 hingga tahun 2012. Kemudian dilakukan analisis evaluasi terhadap masing-masing rasio keuangan menggunakan pendekatan subjektif seperti ditawarkan (Gitman dan Chad 2012) baik bersifat time series, cross sectional dan combined analysis. Pada analisis time series suatu rasio keuangan diklasifikasikan sebagai kinerja "good" apabila mengalami peningkatan yang besar, sedangkan kinerja "ok" apabila tidak banyak mengalami perubahan dan kinerja "poor" apabila mengalami penurunan yang drastis atau besar. Sedangkan pada analisis cross sectional approach suatu rasio keuangan diklasifikasikan sebagai kinerja "good, ok, poor" dengan membandingkan kinerja perusahaan yang sejenis.

\section{HASIL PENELITIAN DAN PEMBAHASAN}

\section{Statistik Deskriptif}

Total perusahaan yang sahamnya tidur pada tahun 2010 berjumlah 66 perusahaan jika dibandingkan dengan jumlah keseluruhan perusahaan yang terdaftar di BEI pada tahun 2010, jumlah saham tidur hanya sekitar 16 persen. Jumlah saham tidur di pasar modal Indonesia tersebut jumlahnya relatif lebih kecil dibandingkan 
dengan yang ada pada bursa Malaysia dan Singapura yang hampir mencapai 50 persen dari total saham yang ada (detik finance, 28 November 2013).

Tabel 2

Statistik Deskriptif

\begin{tabular}{lrrrr}
\hline Panel A : Transaksi Saham & \multicolumn{1}{c}{ Min } & \multicolumn{1}{c}{ Max } & \multicolumn{1}{c}{ Mean } & \multicolumn{1}{c}{ Std. Deviation } \\
\hline Frekuensi (x) & 0 & 56 & 11,09 & 13,23 \\
Harga Saham (Rp) & 50 & 120000 & 7142,71 & 21106,24 \\
Jumlah Saham Beredar (Juta Saham) & 3,5 & 28066,68 & 1021,3 & 3488,55 \\
Kapitalisasi (Miliar Rp) & 5,8 & 6608,25 & 612,63 & 1108,31 \\
\hline Panel B : Kinerja Perusahaan & & & & \\
\hline ROA (\%) & $-37,08$ & 114,63 & 6,29 & 16,77 \\
ROE (\%) & $-265,4$ & 121,7 & 0,15 & 49,28 \\
EPS (Rp) & -4244 & 12514 & 628,65 & 2342,93 \\
& & & & \\
\hline
\end{tabular}

Sumber: Data Sekunder 2014

Tabel 2 pada panel A menunjukan bahwa rata-rata frekuensi perdagangan dari saham tidur hanya 11,09 kali perdagangan untuk setiap tiga bulan selama tahun 2010. Bahkan berdasarkan nilai minimum frekuensi menunjukkan bahwa terdapat perusahaan yang memiliki tingkat transaksi nol yang artinya tidak ada transaksi perdagangan saham sama sekali selama tahun 2010. Perusahaan tersebut adalah PT Asuransi Jasa Tania Tbk, PT Bank Mutiara Tbk, PT Central Omega Resources Tbk, PT Grahamas Citrawisata Tbk, PT Island Concepts Indonesia Tbk, PT Pool Advista Indonesia Tbk, PT Pusako Tarinka Tbk, PT Taisho Pharmaceutical Indonesia Tbk, PT Tira Austenite Tbk dan PT Unitex Tbk.

Harga saham terendah dimiliki oleh PT Bank Mutiara Tbk sebesar Rp50,00, dimana harga tersebut merupakan batasan harga terendah saham di BEI. Selain PT Bank Mutiara Tbk, PT Eratex Djaja Tbk juga memiliki harga saham yang mendekati harga terendah saham di BEI yaitu sebesar Rp59,00. Nilai standar deviasi yang sangat tinggi menunjukkan harga saham yang dimiliki saham tidur ini sangat bervariasi harga saham tertinggi yang dimiliki PT Delta Djakarta Tbk sebesar Rp120.000,00 yang menunjukkan bahwa harga saham tersebut cukup tinggi.

Jumlah saham beredar memiliki rata-rata sebesar 1.021,30 juta saham, dengan jumlah saham beredar tertinggi dimiliki oleh PT Sepatu Bata Tbk sebesar 28.067,00 juta saham dan jumlah saham beredar terendah dimiliki oleh PT Lionmesh Prima Tbk sebesar 3,50 juta saham. Terbatasnya jumlah saham yang dipasarkan diduga menyebabkan tidak banyak transaksi yang terjadi pada saham tersebut, sehingga lama kelamaan saham menjadi tidur.

Kapitalisasi terendah sebesar Rp5,79 Miliar yang dimiliki oleh PT Eratex Djaja Tbk dan rata-rata kapitalisasi yaitu sebesar Rp612,63 Miliar. Dilihat dari sisi 
nilai kapitalisasi pasar tersebut maka saham tersebut termasuk jenis saham lapis ketiga (third layer-small cap). Namun pada nilai maksimum kapitalisasi pasar menunjukan bahwa terdapat perusahaan yang memiliki kapitalisasi pasar jauh diatas Rp1 Triliun yaitu PT Bank Ekonomi Raharja Tbk sebesar Rp6,6 Triliun, tetapi masih masuk kedalam kategori saham tidur.

Panel B, tabel 2 memperlihatkan nilai $R O A$ memiliki rata-rata 6,29 persen dengan nilai maksimum 114,63 persen dimiliki oleh PT ICTSI Jasa Prima Tbk dan nilai minimum -37,08 persen dimiliki oleh PT Alam Karya Unggul Tbk. ROA negatif tersebut menunjukan perusahan yang bersangkutan mengalami kerugian. Terdapat 15 perusahaan yang memiliki rata-rata nilai $R O A$ negatif pada tahun 20102012. Sementara $R O E$ memiliki rata-rata 0,15 persen dengan nilai maksimum 121,70 persen dimiliki oleh PT Toko Gunung Agung Tbk dan nilai minimum -265,40 persen dimiliki oleh PT Central Omega Resources Tbk. Nilai ROE negatif menunjukan perusahaan tidak dapat memberikan imbalan hasil terhadap modal yang diinvestasikan investor pada perusahaan tersebut. Terdapat 16 perusahaan yang memiliki rata-rata nilai $R O E$ negatif pada tahun 2010-2012.

EPS memiliki rata-rata Rp629,00 dengan nilai maksimum Rp12.514,00 dimiliki oleh PT Taisho Pharmaceutical Indonesia Tbk dan nilai minimum Rp4244,00 dimiliki oleh PT Merck Sharp Dohme Pharma Tbk. Nilai EPS negatif menunjukkan perusahaan tidak mampu menghasilkan. Terdapat 16 perusahaan yang memiliki rata-rata nilai EPS negatif pada tahun 2010-2012.

\section{Analisis Kinerja}

Hasil analisis time series pada Tabel 3 yang merupakan kombinasi berbagai rasio profitabilitas, menunjukkan bahwa terdapat 14 perusahaan (21 persen) perusahaan yang memiliki saham tidur berkinerja yang baik pada 2010-2012. Hal ini berarti perusahaan tersebut mengalami pertumbuhan kinerja tiap tahunnya, yaitu 12 perusahaan mengalami pertumbuhan nilai ROA, 12 perusahaan mengalami pertumbuhan nilai $R O E, 22$ perusahaan mengalami pertumbuhan nilai EPS. Berdasarkan uji binomial diketahui terdapat perbedaan yang signifikan jumlah proporsi kinerja perusahaan yang berkinerja "Good" dan "Ok", namun sebagian besar berkinerja "Ok" dan "Poor" sehingga tidak menunjukkan pertumbuhan kinerja yang cukup berarti bahkan banyak juga mengalami penurunan kinerja.

Hasil analisis cross sectional approach yaitu perbandingan rasio saham tidur dengan perusahaan sejenis pada tahun 2012, diketahui perusahaan yang memiliki kinerja baik berdasarkan rasio profitabilitas sebanyak 36 perusahaan (55 persen), jumlah tersebut menunjukkan saham tidur memiliki kinerja yang lebih baik apabila dibandingkan dengan perusahaan sejenis dengan besar kapitalisasi yang relatif sama. Berdasarkan uji binomial diketahui terdapat perbedaan yang signifikan proporsi kinerja perusahaan pada kinerja "Good-Ok" dan "Ok-Poor". Secara keseluruhan kinerja perusahaan yang memiliki saham tidur, berdasarkan hasil combined analysis menunjukkan hanya sebanyak 12 perusahaan (18 persen) yang memiliki kinerja baik, 
yaitu perusahaan mengalami pertumbuhan kinerja pada tahun 2010-2012 dan memiliki kinerja yang lebih baik dibandingkan perusahaan sejenis pada tahun 2012 .

Tabel 3

Analisis Kinerja

\begin{tabular}{|c|c|c|c|c|}
\hline \multicolumn{5}{|c|}{ Panel A : Time Series Analysis } \\
\hline Kinerja & Jumlah & Persentase & Binomial & \\
\hline Good & 14 & $21 \%$ & & \multirow[b]{2}{*}{$0,016^{*}$} \\
\hline & & & & \\
\hline \multirow[t]{2}{*}{$O k$} & 31 & $47 \%$ & & \multirow{2}{*}{0,212} \\
\hline & & & & \\
\hline Poor $_{l)}$ & 21 & $32 \%$ & & 0,311 \\
\hline \multicolumn{5}{|c|}{ Panel B : Cross Sectional Analysis } \\
\hline Good & 36 & $55 \%$ & & \multirow[b]{2}{*}{$0,000^{*}$} \\
\hline \multirow{2}{*}{$O k$} & 3 & $4 \%$ & & \\
\hline & 3 & $4 \%$ & & \multirow[t]{2}{*}{$0,000^{*}$} \\
\hline \multirow[t]{2}{*}{ Poor $_{21}$} & 41 & $41 \%$ & & \\
\hline & & & & 0,649 \\
\hline \multicolumn{5}{|c|}{ Panel C: Combined Analysis } \\
\hline \multirow[t]{2}{*}{ Good } & 12 & $18 \%$ & & \multirow{3}{*}{$0,002 *$} \\
\hline & & & & \\
\hline \multirow[t]{2}{*}{$O k$} & 34 & $52 \%$ & & \\
\hline & & & & \multirow[t]{2}{*}{0,076} \\
\hline \multirow[t]{2}{*}{ Poor $_{31}$} & 20 & $30 \%$ & & \\
\hline & & & & 0,215 \\
\hline
\end{tabular}

Sumber: Data Sekunder 2014

Note: 1),2),3), nilai binomial perbandingan kinerja Poor dan Good

*) signifikan pada $\alpha=5$ persen

Ada kemungkinan kapitalisasi pasar memiliki peran sebagai pemicu suatu saham perusahaan menjadi saham tidur. Untuk membuktikan hal tersebut maka dilakukan analisis terhadap kinerja perusahaan berdasarkan kapitalisasi pasar seperti yang ditunjukkan pada Tabel 4.

Dari nilai kapitalisasi pasar menunjukkan bahwa mayoritas saham tidur memiliki kapitalisasi di bawah satu triliun yaitu sebanyak 51 (77 persen) perusahaan, sehingga saham tidur termasuk jenis saham lapis ketiga. Saham-saham jenis ini memiliki likuiditas dan kapitalisasi pasar yang kecil. Meskipun begitu, terdapat 15 perusahaan yang memiliki kapitalisasi pasar di atas satu triliun tetapi masuk ke dalam kategori saham tidur dan tiga diantaranya memiliki kinerja yang baik. 
Tabel 4

Kinerja Perusahaan Berdasarkan Kapitalisasi Pasar

\begin{tabular}{lccccc}
\hline \multirow{2}{*}{ Kapitalisasi } & \multirow{2}{*}{ Jumlah } & \multirow{2}{*}{ Persentase } & \multicolumn{3}{c}{ Combined Analysis } \\
& & & Good & Ok & Poor \\
\hline$<100$ Miliar & 21 & $32 \%$ & 3 & 10 & 8 \\
100 Miliar $<1$ Triliun & 30 & $45 \%$ & 6 & 16 & 8 \\
$>1$ Triliun & 15 & $23 \%$ & 3 & 9 & 3 \\
\hline Jumlah & 66 & $100 \%$ & 12 & 35 & 19 \\
\hline Sum
\end{tabular}

Sumber: Data Sekunder 2014

\section{PEMBAHASAN}

Rata-rata frekuensi transaksi saham tidur yang dijadikan sampel penelitian menunjukan bahwa hanya sebesar 11,09 kali bahkan beberapa diantaranya transaksi nol atau tidak ada transaksi sama sekali. Frekuensi transaksi tersebut jauh lebih kecil dari persyaratan minimal saham aktif sesuai dengan SE PT BEJ No. SE-03/BEJ II1/I/1994 menyatakan bahwa suatu saham dikatakan aktif apabila frekuensi perdagangan saham selama tiga bulan sebanyak 75 kali atau lebih.

Salah satu penyebab terjadinya saham tidur adalah terbatasnya jumlah saham yang beredar. Hasil analisis memberi bukti bahwa jumlah perusahaan yang sahamnya tidur memiliki jumlah saham beredar relatif rendah dibandingkan dibawah ketentuan jumlah minimal saham yang beredar. Berdasarkan Surat Keputusan Direksi Nomor: Kep-00001/BEI/01-2014 mengenai Perubahan Peraturan I-A tentang Pencatatan Saham dan Efek bersifat Ekuitas selain Saham yang Diterbitkan oleh Perusahaan Tercatat, emiten harus memenuhi jumlah minimal saham yang beredar di publik/free float sebesar 50 juta saham dan minimal 7,5 persen dari jumlah saham dalam modal disetor. Paralel dengan jumlah saham tersebut, rata-rata kapitalisasi pasarnya hanya sebesar Rp612,63 Miliar, maka tidak mengherankan kalau saham tidur mayoritas termasuk jenis saham lapis ketiga yang memiliki likuiditas dan kapitalisasi pasar yang kecil, yaitu dibawah Rp1 Triliun. Dengan nilai kapitalisasi yang rendah kemungkinan saham dikuasai oleh investor institusi dan pemilik saham lama (pendiri perusahaan) untuk investasi jangka panjang. Selain itu, ada kemungkinan juga dengan nilai kapitalisasi rendah tidak memberikan daya tarik keuntungan yang relatif tinggi bagi investor karena sehingga enggan terlibat dalam transaksi saham tersebut.

Tidak dapat dipungkiri bahwa investor memberikan perhatian yang besar terhadap kinerja perusahaan sebagai bahan pertimbangan dalam membuat keputusan investasi saham karena pada pasar efisien harga saham merefleksikan kinerja perusahaan. Perusahaan yang kinerjanya bagus maka saham akan cenderung menjadi buruan para investor dan sebaliknya. Berdasarkan hasil analisis selama periode 20102012, dari segi profitabilitas ( $R O A, R O E$ dan $E P S$ ) menunjukan kinerja perusahaan yang sahamnya tidur hanya sedikit yang mengalami pertumbuhan. Selain itu, juga 
cenderung tidak lebih baik kinerjanya dibandingkan perusahaan sejenis. Dengan demikian memberi indikasi bahwa karena kinerjanya kurang bagus tersebut menjadikan sahamya tidak diminati oleh investor dan pada gilirannya menjadi tidak likuid atau saham tidur. Sebaliknya perusahaan yang berkinerja bagus cenderung akan diminati investor sehingga akan sahamnya akan likuid. Hal ini sesui dengan hasil penelitian sebelumnya seperti yang dilakukan oleh Fang et al. (2009), Wira (2012), Hansen \& Kim (2013) yang telah membuktikan bahwa perusahaan yang sahamnya likuid memiliki kinerja bagus. Namun Nofsinger (2005) mengingatkan adanya reprentativeness bias dalam berinvestasi. Investor seringkali terjebak pada pertimbangan kinerja perusahaan pada masa lalu untuk menilai prospek perusahaan. Ada kemungkinan kinerja masa lalunya bagus ternyata tidak senantiasa prospeknya bagus sehingga kinerja yang bagus tidak identik dengan investasi yang bagus.

\section{SIMPULAN}

Penelitian ini berusaha melakukan eksplorasi apa yang melatarbelakangi munculnya fenomena saham tidur. Dengan menggunakan analisis deskriptif terhadap 66 perusahan yang sahamnya tidur di BEI selama periode 2010-2012, diketemukan jawaban bahwa perusahaan tersebut memiliki nilai kapitalisasi yang rendah. Selain itu dari sisi kinerja, perusahaan yang memiliki saham tidur cenderung pertumbuhan profitabilitasnya kurang bagus dan demikian juga jika dibandingkan dengan perusahaan yang sejenis. Hal ini memberikan implikasi bahwa perusahan dengan small cap dan kinerjanya dinilai buruk berpeluang besar sahamnya tidak dimintai dan tidak tertutup kemungkinan menjadi saham tidur. Dengan demikian nilai kapitalisasi yang sering dijadikan proksi ukuran besaran suatu perusahaan dan juga kondisi fundamental perusahaan menjadi pertimbangan tersendiri bagi investor di BEI untuk memilih jenis saham yang akan dikoleksi baik untuk kepentingan portofolio maupun trading

Penelitian ini tidak terlepas adanya keterbatasan yang dapat dijadikaan peluang agenda penelitian mendatang antara lain belum dikaitkan dengan porsi kepemilikan institusional dan individual sebagai penyebab terjadi saham tidur. Selain itu, belum menangkap dinamika transaksi saham tidur yaitu apakah saham tidur hanya bersifat sementara atau jangka panjang.

\section{DAFTAR PUSTAKA}

Afiff, S., dan S. P. D. Anantadjaya. 2013. CSR dan peformance: Any evidence from Indonesian LQ45. Review of Integrative Bussiness and Economics Research. Vol.2.

Basir, S., dan H. Fakhrudin. 2005. Aksi Korporasi (Stretegi Untuk Meningkatkan Nilai Saham Melalui Aksi Korposasi). Jakarta: Salemba Empat. 
Bhunia, A., S. S. Mukhuti, dan S. G. Roy. 2011. Financial performance analysis-A case study. Research Journal of Social Sciences. Vol.3 No.3: 269-275.

Detik Finance. 2013. Bagaimana caranya 'membangunkan' saham tidur? Available at http://finance.detik.com/read.

Easley, D., N. Kiefer, M. O’Hara, dan J. Paperman. 1996. Liquidity, information and infrequently traded stocks. Journal of Finance. Vol.51: 1405-1436.

Fang, V. W., T. H. Noe, dan S. Tice. 2009. Stock market liquidity and firm value. Journal of Financial Economics. Vol.94: 150-169.

Gitman, L. J., dan C. J. Zulter. 2012. Principles of Managerial Finance. Thirteenth Edition. England: Pearson.

Hansen, S., dan K. S. Suk. 2013. Influence of stock liquidity to firm value in indonesian stock market. The 2013 IBEA International Conference on Business, Economics, and Accounting. 20 - 23 March 2013 BangkokThailand.

Indonesia Stock Exchange (Bursa Efek Indonesia). Laporan keuangan dan tahunan. Available at $h t t p: / / w w w . i d x . c o . i d$.

Investor Daily Indonesia. 2011. Saham tidur belum cerminkan kinerja buruk.

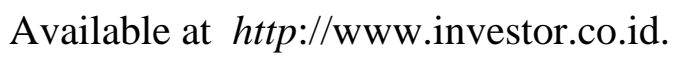

Ipot News. 2011. Aksi buru saham dorong penguatan. Available at http://www.ipotnews.com.

Kallapur, S., dan M. K. Trombley. 2001. The investment opportunity set: Determinants, consequences and measurement. Managerial Finance. Vol.27 No.3: 3-15.

Nofsinger, J. R. 2005. The Psychology of Investing. New Jersey: Prentice Hall.

Pakar Investasi. 2013. Saham kok bisa tidur? Available at http://pakarinvestasi.com.

Puspitasari, N. 2012. Kinerja financial dan kesempatan investasi perusahaan bertumbuh dan tidak bertumbuh. Bisma Jurnal Bisnis dan Manajemen. Vol.6 No.1: 13-33.

Salim, J. 2010. 30 Strategi Cerdas Investasi Saham Paling Menguntungkan. Jakarta: Elex Media Komputindo.

Setyawan, I. R., dan R. Syaftina. 2013. Assessing financial performance of issuer LQ 45 in the IDX at period 2002-2006. Available at http:/ssrn.com.

Horne, J. C. V., dan J. M. Wachowicz. 2013. Prinsip-Prinsip Manajemen Keuangan. Edisi 13, Buku 1. Jakarta: Salemba Empat.

Wira, V. 2012. Pengaruh kinerja perusahaan terhadap likuiditas saham menggunakan tranding turnover (Studi kasus perusahaan yang terdaftar di bursa efek 
indonesia). Jurnal Manajemen dan Kewirausahaan. Vol.3 No.2 (Mei): 2086 -5031 . 